\title{
Development of Pavement Maintenance Management System (PMMS) of Urban Road Network Using HDM-4 Model
}

\author{
Tanuj Chopra $^{a}$, Manoranjan Parida $^{b}$, Naveen Kwatra ${ }^{c}$, Jyoti Mandhani $^{d}$ \\ ${ }^{a, c, d}$ Department of Civil Engineering, Thapar University,Patiala,India \\ ${ }^{b}$ Department of Civil Engineering, Indian Institute of Technology, Roorkee, India \\ *E-mail address: tchopra@thapar.edu
}

Received date: January 2017

\begin{abstract}
The aim of the study is to develop Pavement Maintenance Management System (PMMS) for four road sections of urban road network (Patiala, Punjab, India) using Highway Development and Management (HDM-4) model. The HDM-4 provides a deterministic approach in data input and process data of existing road condition, traffic volume and pavement composition to predict road deterioration as per the urban road conditions in terms of International Roughness Index (IRI) value. This study presents the use of HDM-4 model for the computation of optimum Maintenance and Rehabilitation $(M \& R)$ strategy for each road section and comparative study of scheduled and condition responsive $M \& R$ strategies. The results of present study will be useful for gaining better support for decision-makers for adequate and timely fund allocations for preservation of the urban road network.
\end{abstract}

Keywords: Pavement, management, maintenance, HDM-4, urban road, predict, road deterioration.

\section{Introduction}

Construction of road network involves substantial investment and therefore proper maintenance of these assets is of paramount importance. It is found that the actual available maintenance expenditure amount is much less than what is required for urban roads. It is a complex problem of matching of resources, time, materials, labour, equipment, funds, design and decision making. Therefore, maintenance and preservation of pavements should have a great national interest. Pavement Maintenance Management System (PMMS) consists of a comprehensive, coordinated, sets of activities associated with the planning, design, construction, maintenance and evaluation. Thus, PMMS can be used in directing and controlling maintenance resources for optimum benefits. Indeed, as a developing state, Punjab (India) pavements have some threats like increase rate of deterioration, rapid traffic growth, poor maintenance, overloading of vehicles, improper design and implementation, insufficient information for decision making and inefficient current traditional management system. Therefore, it is very essential to develop PMMS for the urban roads of Punjab and in this study, Patiala city has been taken to develop PMMS. Highway Development and Management Tool (HDM-4) was developed by World Bank to offer a powerful system for road maintenance and investment alternatives analysis, Archondo-Caallao [4]. HDM-4 analytical framework is based on the concept of pavement life cycle analysis. This is applied to predict road deterioration effects, work effect, user effect etc. Many researchers are working on the development of PMMS and effect of road surface deformations (Aydin and Topal [5], Ben-Edigbe [7], Ben-Edigbe and Ferguson [6], Ghasemlou et al. [9], Kerali et al. 
[16], Pienaar et al. [26], Aggarwal et al. [1], Aggarwal et al. [2], Shah et al. [29], Girimath et al. [10], Gupta et al. [11]). Jain et al. [14] calibrated the HDM-4 pavement deterioration models for Indian National Highway Network located in the Uttar Pradesh and Uttaranchal states of India. They developed pavement performance prediction models for the major modes of distress, including cracking, raveling, potholes, and roughness on the basis of collected data. They also compared Indian deterioration models with HDM-4 deterioration models. Gupta et al. [11] determined the remaining service life of three road sections of Panchkula (Haryana). They concluded that from remaining service life values, all the selected road sections (in their study) would become candidates for reconstruction within 4 to 6 years without any maintenance work assigned during analysis period. Aggarwal et al. [3] developed PMMS for five Indian National Highway network using HDM-4 model; five National Highways, all were within the boundaries of Dehradun \& Haridwar districts of Uttarakhand state and Saharanpur \& Muzaffarpur districts of Uttar Pradesh state, comprising of total length of $310 \mathrm{~km}$. Naidu et al. [24] developed maintenance management plan based on economics of life cycle costs using HDM-4 and he selected Inner Ring Road of New Delhi in his study. Dattatreya et al. [8] carried out a study on primary roads of Bangalore Metropolitan Development Authority Area. On the basis of their study, the requirements for the first stage road improvement program were worked out, consisting of strengthening and resurfacing of pavements, improvements in the drainage system and sidewalks and adopting measures to prevent early damages to pavements due to the leakage of water from pipes underneath the pavements and cutting of pavements across the roads at frequent intervals to take the service lines. Reddy et al. [28] developed a method of allocation of maintenance and rehabilitation costs based on the volume of commercial vehicles duly considering the load carried by them and the performance of pavements. They determined the cost allocation strategy for optimum maintenance and strengthening considering the yearly increase in vehicle operation cost due to the cumulative traffic loading during the analysis period. Reddy and Veeraragavan [27] developed a simple priority-ranking module that provided a systematic procedure to prioritize road pavement sections for maintenance depending upon the budget constraints. In their module, pavement sections under the jurisdiction of a highway agency were prioritized based on an overall pavement performance index derived from a combination of pavement surface distresses, traffic information and expert opinion. Jain et al. [15] developed optimum maintenance and rehabilitation strategy for multilane national highways by using programme analysis component of HDM-4 software. They had selected one expressway (from Noida to Greater Noida) divided into five sub-sections and one National Highway (NH-24, GhaziabadHapur) divided into eight sub-sections. They concluded that M\&R strategy which had higher NPV/CAP ratio was considered as optimum for the road section. On the basis of the economic analysis summary, they selected ' $25 \mathrm{~mm}$ SDBC Reseal and $40 \mathrm{~mm}$ BC overlay' for Expressway sections and for NH- 24 sections 'Thick Overlay of $40 \mathrm{~mm} \mathrm{BC'}$ as the optimum M\&R strategy having the maximum NPV/Cost among other alternatives.

The literature of PMMS for Indian road conditions revealed that there is no any PMMS developed for Indian urban roads and all the related studies of PMMS have been done for high category roads like national highways and expressways. The aims of the present study are to develop PMMS for urban road network of Patiala (Punjab, India) using HDM-4 model to determine optimum Maintenance and Rehabilitation (M\&R) strategy for road sections of Patiala city using Project Analysis in HDM-4 model, prioritize Patiala city road sections based on optimum M\&R strategy and to perform the comparative analysis of scheduled and condition responsive $M \& R$ strategies. The analysis period of 12 years (2017-2028) and for optimum M\&R strategy Net Present Value (NPV)/Cost ratio have been taken. 


\section{Materials and Methods}

\subsection{Selection of Urban Road Sections}

Patiala city (Punjab, India) has urban road network comprising of 52 road sections. The whole road network comes under the jurisdiction of Punjab Roads and Bridges Development Board (PR \& BDB). In the present study, four road sections of Patiala each comprise of one $\mathrm{km}$ stretch have been selected and details of selected road sections of city have been shown in Table 1.

\subsection{Data Collection and Analysis}

Primary data for PMMS include pavement condition ratings, costs, roadway construction and maintenance history as well as traffic loading. To identify and evaluate pavement conditions and determine the causes of deterioration, a pavement evaluation system should be developed that is rapid, economical and easily repeatable. For this, pavement condition data has been collected periodically to document the changes of pavement condition.

The process of data collection was classified under following four categories:

- Road Network Data

- Traffic Volume and Vehicle Composition Data

- Maintenance and Rehabilitation (M\&R) Works Data

- Road User Cost (RUC) Data

Road Network data refer to inventory data, pavement history data, and pavement condition data etc. Vehicle Fleet data include representation of vehicles with their basic characteristics. Maintenance and Rehabilitation Works data refer to details of maintenance activities for the road section. Costs data include road use cost data and data of cost of maintenance works.

Table 1. Details of selected road sections of Patiala city

\begin{tabular}{|c|c|c|c|c|c|}
\hline $\begin{array}{l}\text { Section } \\
\text { ID }\end{array}$ & $\begin{array}{l}\text { Section } \\
\text { Name }\end{array}$ & Description & $\begin{array}{c}\text { Section } \\
\text { Length } \\
(\mathrm{Km})\end{array}$ & Road Properties & $\begin{array}{l}\text { Classification of } \\
\text { Road }\end{array}$ \\
\hline PR-01 & $\begin{array}{l}\text { Bhadson } \\
\text { Road }\end{array}$ & $\begin{array}{l}\text { From Central Jail to Sarabha } \\
\text { Nagar }\end{array}$ & 1.00 & $\begin{array}{l}\text { Two-Lane Wide } \\
\text { Road }\end{array}$ & Collector Street \\
\hline PR-02 & $\begin{array}{l}\text { Bhupinder } \\
\text { Road }\end{array}$ & $\begin{array}{c}\text { From Thapar University to } \\
\text { Sahni's Bakery }\end{array}$ & 1.00 & $\begin{array}{l}\text { Four-Lane divided } \\
\text { Road }\end{array}$ & Collector Street \\
\hline PR-03 & Passey Road & $\begin{array}{c}\text { From Thapar University to } \\
\text { Charan Bagh }\end{array}$ & 1.00 & $\begin{array}{l}\text { Narrow Two-Lane } \\
\text { Road }\end{array}$ & Collector Street \\
\hline PR-04 & $\begin{array}{l}\text { Ghuman } \\
\text { Road }\end{array}$ & $\begin{array}{c}\text { From Passey Road to Civil } \\
\text { Lines }\end{array}$ & 1.00 & $\begin{array}{c}\text { Two-Lane } \\
\text { Standard Road }\end{array}$ & Local Street \\
\hline
\end{tabular}

\subsubsection{Road Network Data}

\subsubsection{Road Inventory Data}

Road inventory data collection consists of road length $(\mathrm{m})$, lane width (m), shoulder width $(\mathrm{m})$, geometries of road sections, traffic flow pattern, design speed $(\mathrm{km} / \mathrm{h})$, flow direction and climate zone. Road sections have been visually inspected to get relevant information. Details of road section inventory data has been presented in Table 2(a) and Table 2(b). 
Table 2(a). Details of Inventory Data - 1

\begin{tabular}{cccc}
\hline Section ID & Section Length $(\mathrm{km})$ & Lane width $(\mathrm{m})$ & Shoulder Width $(\mathrm{m})$ \\
\hline PR-01 & 1.00 & 8.4 & 1.4 \\
PR-02 & 1.00 & 6.7 & 1.9 \\
PR-03 & 1.00 & 6.5 & 1.6 \\
PR-04 & 1.00 & 7.2 & 1.9 \\
\hline
\end{tabular}

\subsubsection{Pavement History Data}

Pavement history data (type of pavement, year of last construction, surfacing and maintenance) has been collected from Public Works Department (PWD) office and Municipal Corporation of Patiala records from the year 2011 and 2015, Government of Punjab [17]. Details of pavement history data of road are presented in Table 3.

Table 2(b). Details of Inventory Data - 2

\begin{tabular}{cccccc}
\hline Section ID & $\begin{array}{c}\text { Traffic Flow } \\
\text { Pattern }\end{array}$ & $\begin{array}{c}\text { Flow } \\
\text { Direction }\end{array}$ & $\begin{array}{c}\text { Design Speed } \\
(\mathrm{km} / \mathrm{hr})\end{array}$ & Climate Zone & $\begin{array}{c}\text { Drainage } \\
\text { condition }\end{array}$ \\
\hline PR-01 & Inter- Urban & Two-way & 50 & North India Plain & Good \\
PR-02 & Inter-Urban & Two-way & 50 & North India Plain & Fair \\
PR-03 & Inter-Urban & Two-way & 50 & North India Plain & Excellent \\
PR-04 & Inter-Urban & Two-way & 30 & North India Plain & Poor \\
\hline
\end{tabular}

Table 3. Pavement history data

\begin{tabular}{|c|c|c|c|c|c|c|c|}
\hline $\begin{array}{c}\text { Section } \\
\text { ID }\end{array}$ & $\begin{array}{c}\text { Surfacing } \\
\text { Material } \\
\text { Type }\end{array}$ & $\begin{array}{c}\text { Current } \\
\text { Surface } \\
\text { Thickness } \\
(\mathrm{mm})\end{array}$ & $\begin{array}{c}\text { Previous } \\
\text { Surface } \\
\text { Thickness } \\
(\mathrm{mm})\end{array}$ & $\begin{array}{c}\text { Last } \\
\text { Construction } \\
\text { Year }\end{array}$ & $\begin{array}{c}\text { Last } \\
\text { Rehabilitation } \\
\text { Year }\end{array}$ & $\begin{array}{c}\text { Last } \\
\text { Surfacing } \\
\text { Year }\end{array}$ & $\begin{array}{c}\text { Last } \\
\text { Preventive } \\
\text { Treatment } \\
\text { Year }\end{array}$ \\
\hline PR-01 & & 75 & 50 & 2003 & 2008 & 2013 & 2014 \\
\hline PR-02 & $\bar{\sigma} \frac{\pi}{0}$ & 75 & 50 & 2003 & 2009 & 2013 & 2014 \\
\hline PR-03 & 当鹃 & 75 & 50 & 2004 & 2010 & 2014 & 2014 \\
\hline PR-04 & 记 & 75 & 50 & 2004 & 2009 & 2012 & 2012 \\
\hline
\end{tabular}

\subsubsection{Functional and Structural Evaluation of Road Pavements}

The functional evaluation like roughness measurement survey has been conducted to assess the riding comfort and safety over the pavement section as experienced by road users. Road roughness refers to surface irregularities in the longitudinal direction and has been measured with fifth wheel bump integrator or simply known as 'Roughometer'. The equipment has been towed by pick-up and operated with speed of $30 \mathrm{kmph}$ and shown in Figure 1. Accumulated bumps (in cms) has been noted down corresponding to length travelled (in $\mathrm{km}$ ).

$$
\text { Unevenness Index }(\mathrm{UI})=\text { Bumps in } \mathrm{cm} / \text { Length travelled in } \mathrm{km}
$$

UI value has been converted into International Roughness Index (IRI in $\mathrm{m} / \mathrm{km}$ ) by using the following equation given by Odoki and Kerali [25]: 


$$
I R I=\left(\frac{1}{630} \times U I\right)^{1 / 1.12}
$$

The structural evaluation has been carried out to assess the pavement's structural ability to receive wheel loads plying over it using rebound deflection measurements with the help of 'Benkelman Beam Defection (BB def $)$ Test' as shown in Figure 2. The test was conducted as per IRC: 81-1997 guidelines [12]. The Adjusted Structural Number (SNP) was calculated from deflection values by using the following equation given by Odoki and Kerali [25] and Table 4 presents the functional and structural evaluation data and Table 5 presents calibration factors for HDM-4 deterioration models.

For granular base courses

$$
\mathrm{BB}_{\mathrm{def}}=6.5 *(\mathrm{SNP})^{-1.6}
$$

For bituminous base courses

$$
\mathrm{BB}_{\mathrm{def}}=3.5 *(\mathrm{SNP})^{-1.6}
$$

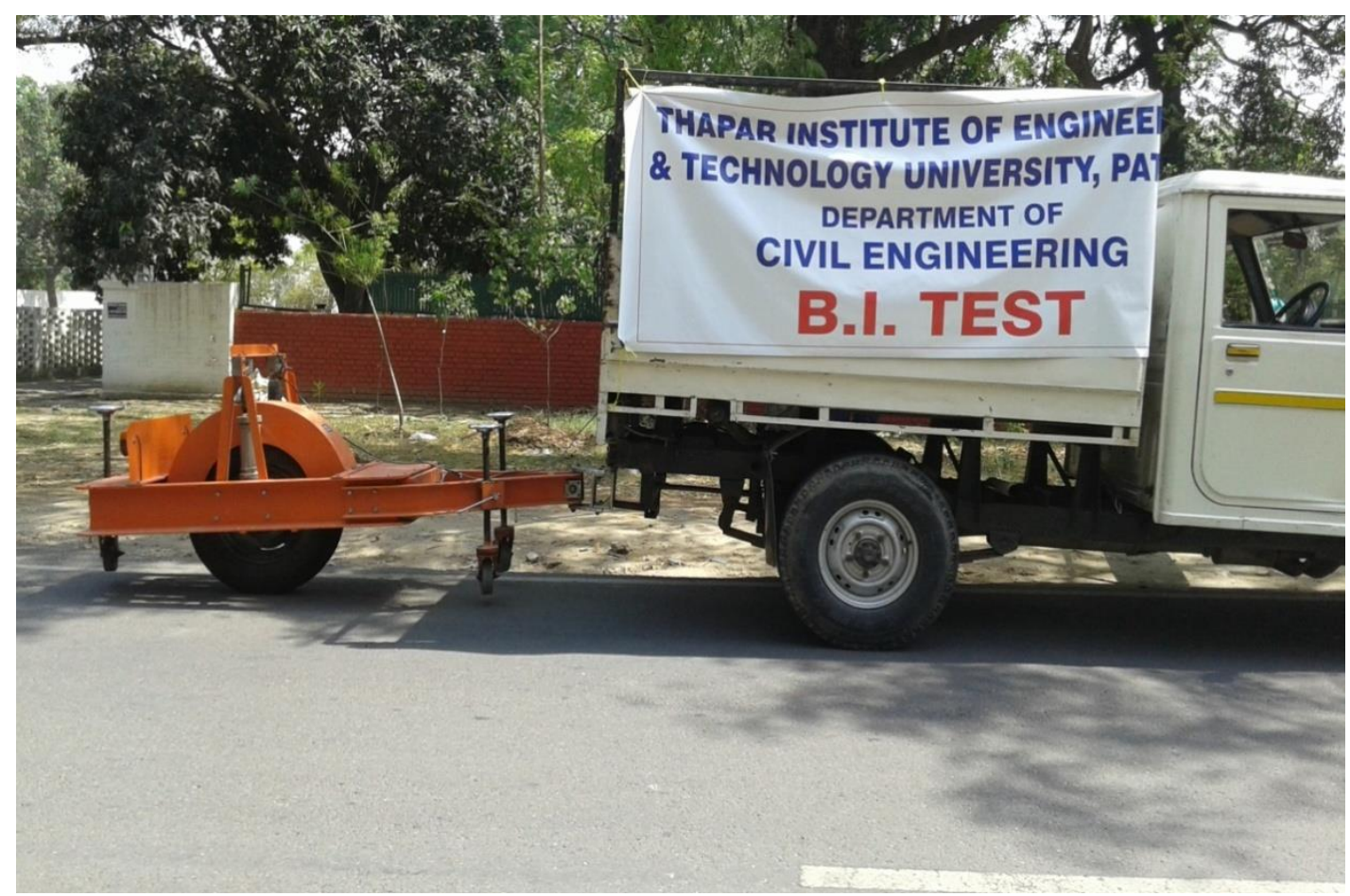

\begin{tabular}{|c|c|c|c|c|}
\hline Section ID & $\begin{array}{l}\text { Condition } \\
\text { Year }\end{array}$ & $\begin{array}{l}\text { Roughness, IRI } \\
(\mathrm{m} / \mathrm{km})\end{array}$ & $\begin{array}{l}\text { Benkelman Beam } \\
\text { Deflection (mm) }\end{array}$ & $\begin{array}{c}\text { Adjusted Structural Number, } \\
\text { (SNP) }\end{array}$ \\
\hline $\begin{array}{l}\text { PR-01 } \\
\end{array}$ & & 1.99 & 0.43 & 5.46 \\
\hline PR-02 & 0 & 2.25 & 0.48 & 5.09 \\
\hline PR-03 & ì & 2.16 & 0.44 & 5.38 \\
\hline PR-04 & & 3.85 & 0.51 & 4.91 \\
\hline
\end{tabular}

Fig. 1. Bump integrator test (Roughness test)

Table 4. Functional and structural evaluation data 
Table 5. Calibration factors for HDM-4 deterioration models

\begin{tabular}{lc}
\hline \multicolumn{1}{c}{ Model Description } & Average Calibration Factor \\
\hline Cracking Initiation Model & 0.43 \\
Cracking Progression Model & 1.25 \\
Ravelling Initiation Model & 0.37 \\
Ravelling Progression Model & 0.52 \\
Pothole Initiation Model & 0.45 \\
Pothole Progression Model & 0.95 \\
Roughness Progression Model & 0.85 \\
Rutting Progression Model & 1.00 \\
\hline
\end{tabular}

Aggarwal et al. [1] proposed the calibration factor is equal to 0.85 for National Highway Network when SNP range was of 3.0 - 5.3. It can be observed from Table 4 that SNP is in the range of $4.91-5.46$ for present study, therefore the same calibration factor has been taken here. For pavement material evaluation, test pits of size $60 \mathrm{~cm} \times 60 \mathrm{~cm}$ have been dugged up for all the selected road sections to get information such as crust layer's thickness, California Bearing Ratio (CBR) of sub-grade soil and 'Atterberg Limits'. After taking the samples, laboratory tests such as light compaction test, CBR test, 'Atterberg Limits' test have been conducted on the collected soil. Table 6 presents the results of laboratory test on collected soil samples for selected road sections.

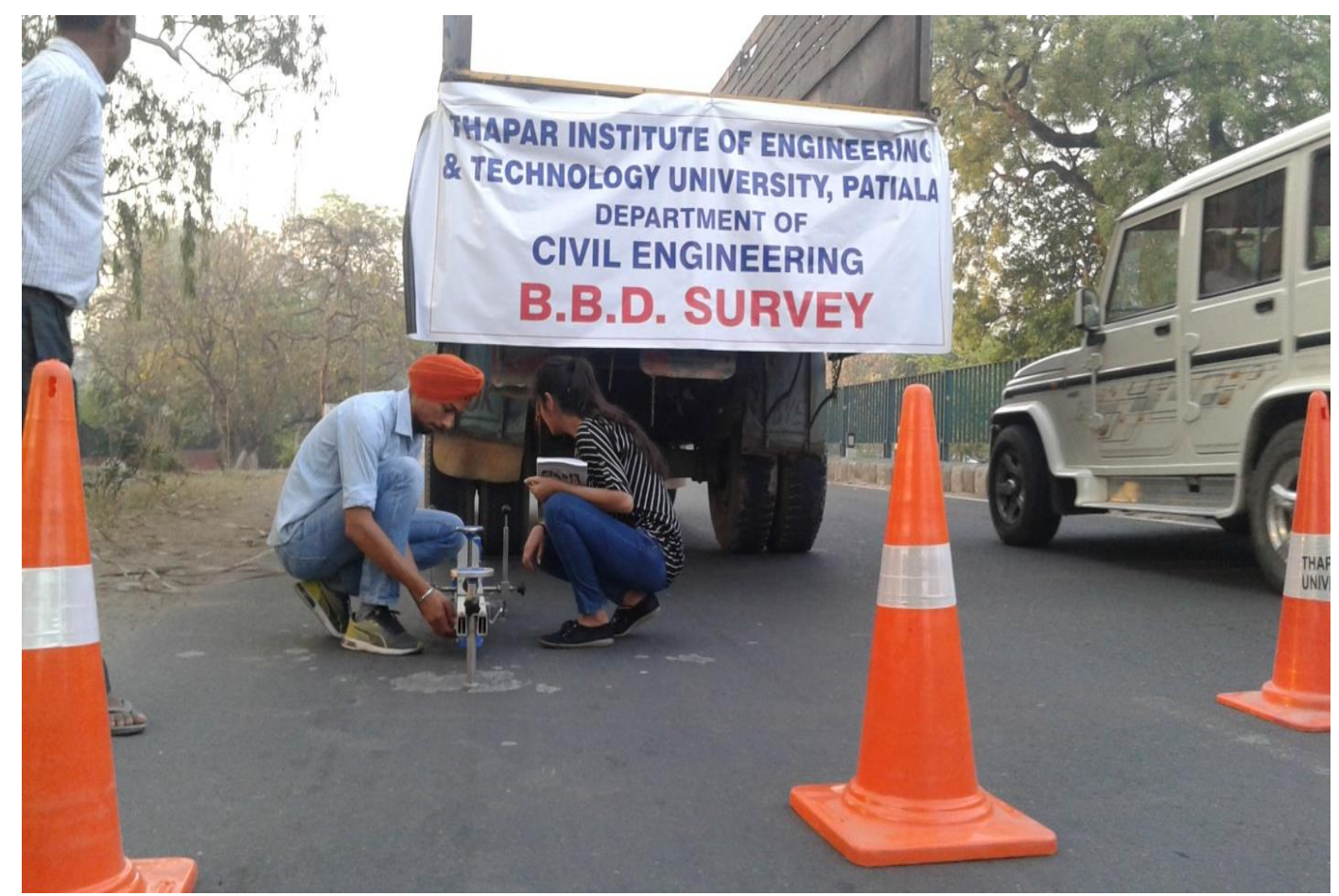

Fig. 2. Benkelman beam deflection test

Table 6. Laboratory test results of collected soil sample for all roads sections

\begin{tabular}{|c|c|c|c|c|c|}
\hline \multirow{2}{*}{$\begin{array}{l}\text { Section } \\
\text { ID }\end{array}$} & \multirow{2}{*}{$\begin{array}{c}\text { Optimum Moisture } \\
\text { Content (OMC in } \\
\%)\end{array}$} & \multicolumn{3}{|c|}{ Atterberg Limit (\%) } & \multirow{2}{*}{$\begin{array}{c}\text { CBR (\%) on } \\
\text { Soaked sample }\end{array}$} \\
\hline & & Liquid Limit & Plastic Limit & Plasticity Index & \\
\hline PR-01 & 12.4 & 19 & 15 & 4 & 5.2 \\
\hline PR-02 & 11.7 & 17 & 14 & 3 & 5.6 \\
\hline PR-03 & 13.8 & 22 & 16 & 6 & 4.5 \\
\hline PR-04 & 14.2 & 24 & 17 & 7 & 4.3 \\
\hline
\end{tabular}




\subsection{Traffic Volume and Vehicle Composition Data}

Traffic volume counts are conducted manually for 72 hours consecutively by engaging adequate number of enumerators in individual road section. In the present study, traffic volume data and vehicular composition data have been collected from Municipal Corporation, Patiala. Annual Average Daily Traffic (AADT) for each section has been calculated by summing up the products of number of individual vehicle and its Passenger Car Space Equivalent (PCSE) factor. Table 7 presents the traffic volume of each section. Patiala road traffic comprises of both Motorized (MT) and Non-Motorized (NMT) vehicles. Percentage vehicle composition and Annual growth rate of vehicle for each road section has been provided in Table 8 .

Table 7. Average Daily Traffic (AADT) data for road sections

\begin{tabular}{ccccc}
\hline Section ID & $\begin{array}{c}\text { Motorized AADT } \\
\text { (in PCSE) }\end{array}$ & $\begin{array}{c}\text { Non-Motorized } \\
\text { AADT }\end{array}$ & AADT year & Traffic Volume \\
\hline PR-01 & 14,232 & 2,019 & 2016 & High \\
PR-02 & 16,550 & 3,320 & 2016 & High \\
PR-03 & 11,856 & 2,247 & 2016 & High \\
PR-04 & 6,120 & 1,885 & 2016 & Medium \\
\hline
\end{tabular}

Table 8. Vehicular composition and annual growth rate

\begin{tabular}{|c|c|c|c|c|c|c|c|c|c|}
\hline \multirow{3}{*}{ Vehicle Type } & \multicolumn{8}{|c|}{ Composition of Traffic Flow (\%) } & \multirow{3}{*}{$\begin{array}{c}\text { Annual } \\
\text { Average } \\
\text { Growth Rate } \\
(\%)\end{array}$} \\
\hline & \multicolumn{2}{|c|}{ PR-01 } & \multicolumn{2}{|c|}{ PR-02 } & \multicolumn{2}{|c|}{$\overline{\text { PR-03 }}$} & \multicolumn{2}{|c|}{ PR-04 } & \\
\hline & MT & NMT & MT & NMT & MT & NMT & MT & NMT & \\
\hline Car/Jeep/Van & 29.8 & - & 32.4 & - & 35.4 & - & 33.3 & - & 8.5 \\
\hline Mini Bus & 3.90 & - & 0.60 & - & 0.60 & - & - & - & 3.7 \\
\hline Bus & 3.60 & - & 0.80 & - & 0.80 & - & - & - & 4.0 \\
\hline Two Wheeler & 39.8 & - & 43.9 & - & 41.0 & - & 49.1 & - & 4.2 \\
\hline Mini Truck & 2.10 & - & 1.50 & - & 1.50 & - & 1.50 & - & 12.5 \\
\hline Truck (Medium) & 3.40 & - & 0.80 & - & - & - & - & - & 5.0 \\
\hline Tractor/ & 2.60 & - & 1.50 & - & 1.50 & - & 1.50 & - & 5.9 \\
\hline \multicolumn{10}{|l|}{ Trolley } \\
\hline Auto Rickshaw & 14.8 & - & 18.5 & - & 19.2 & - & 14.6 & - & 5.4 \\
\hline Cycle & - & 46 & - & 49 & - & 56 & - & 60 & 3.4 \\
\hline Man-Driven & - & 52 & - & 50 & - & 43 & - & 39 & 3.4 \\
\hline \multicolumn{10}{|l|}{ Rickshaw } \\
\hline Cart & - & 2 & & 1 & - & 1 & - & 1 & 3.4 \\
\hline Total & 100 & 100 & 100 & 100 & 100 & 100 & 100 & 100 & \\
\hline
\end{tabular}

\subsection{Maintenance and Rehabilitation Works Data}

Maintenance serviceability levels for urban roads are suggested by Ministry of Road Transport and Highways (MORT\&H) [23]. The suggested serviceability levels and the limiting levels of surface defects based on measurement of roughness, cracking, rutting etc. as per, (MORT\&H, [23]), are given in Table 9. 
Table 9. Maintenance serviceability levels for urban roads

\begin{tabular}{|c|c|c|c|c|}
\hline \multirow[b]{2}{*}{ S. No. } & \multirow[b]{2}{*}{ Serviceability Indicator } & \multicolumn{3}{|c|}{ Serviceability Levels } \\
\hline & & Arterial Roads & $\begin{array}{l}\text { Sub-Arterial } \\
\text { Roads }\end{array}$ & Other Roads \\
\hline 1. & $\begin{array}{l}\text { Roughness by Bump Integrator } \\
\text { (max. permissible) Equivalent IRI }\end{array}$ & $2000 \mathrm{~mm} / \mathrm{km}$ & $\begin{array}{c}3000 \mathrm{~mm} / \mathrm{km} \\
4.0 \mathrm{~m} / \mathrm{km}\end{array}$ & $4000 \mathrm{~mm} / \mathrm{km}$ \\
\hline & (Odaki and Kerali, 2000) & $2.8 \mathrm{~m} / \mathrm{km}$ & & $5.2 \mathrm{~m} / \mathrm{km}$ \\
\hline 2. & Potholes per km (max. number) & Nil & $2-3$ & $4-8$ \\
\hline 3. & $\begin{array}{l}\text { Cracking and patching area } \\
\text { (max. permissible) }\end{array}$ & 5 percent & 10 percent & $10-15$ percent \\
\hline 4. & $\begin{array}{l}\text { Rutting - } 20 \mathrm{~mm} \\
\text { (max. permissible) }\end{array}$ & $5 \mathrm{~mm}$ & $5-10 \mathrm{~mm}$ & $10-20 \mathrm{~mm}$ \\
\hline 5. & Skid number (min. desirable) & $50 \mathrm{SN}$ & $40 \mathrm{SN}$ & $35 \mathrm{SN}$ \\
\hline
\end{tabular}

For the present study, maintenance standard has been formed with basic design details and intervention criteria. The maintenance work standard for all road sections for reconstruction is condition responsive work i.e., $200 \mathrm{~mm}$ wet mix macadam, $75 \mathrm{~mm}$ dense bituminous macadam and $40 \mathrm{~mm}$ bituminous concrete with the intervention criteria of 'roughness $>=8$ IRI'.

\subsection{Cost Data of M\&R Works}

For the present study, the costs specified for urban roads in MORT\&H, [19] is applicable. The cost (given in MORT\&H, [19]) is relevant for the base year 1999-2000 and to include the effect of inflation, these costs are necessitated to be updated for application in consequent years. This has been made possible by provision of a mathematical model for annual updation of costs by linking labour component of the costs with Consumer Price Index (CPI), material component with Wholesale Price Index (WPI) and machinery component with average price of fuel (MORT\&H, [19]).

$$
\text { Percentage Increase in cost }=\left(\frac{\mathrm{F}_{\mathrm{L}}\left(\mathrm{I}_{1}-\mathrm{I}_{0}\right)}{\mathrm{I}_{0}}+\frac{\mathrm{F}_{\mathrm{M}}\left(\mathrm{W}_{1}-\mathrm{W}_{0}\right)}{\mathrm{W}_{0}}+\frac{\mathrm{F}_{\mathrm{F}}\left(\mathrm{F}_{1}-\mathrm{F}_{0}\right)}{\mathrm{F}_{0}}\right) * 100
$$

Where, $\mathrm{F}_{\mathrm{L}}, \mathrm{F}_{\mathrm{M}}$ and $\mathrm{F}_{\mathrm{F}}$ are the labour component, material component and machinery component of the cost, respectively. $\mathrm{I}_{1}, \mathrm{~W}_{1}$ and $\mathrm{F}_{1}$ are the annual average CPI, WPI and fuel price, respectively, for the stated year (2015-16 in the present study) and $\mathrm{I}_{0}, \mathrm{~W}_{0}$ and $\mathrm{F}_{0}$ are the annual average CPI, WPI and fuel price, respectively, for the base year 1999-2000. The percentage increase in cost for the year 2015-16 over the base year costs for routine maintenance is $125.26 \%$ and periodic maintenance is $205.40 \%$. Table 10 presents updated economic cost data of M\& R works for year 2016. 
Table 10. Updated economic cost data of M\&R works for year 2016

\begin{tabular}{|c|c|c|}
\hline S. No. & Type of M\&R Work & $\begin{array}{c}\text { Cost per sq. m of } \\
\text { Surface Area, Rs }(\$)\end{array}$ \\
\hline \multicolumn{3}{|c|}{ Routine Maintenance } \\
\hline 1. & Crack Sealing (All Cracks) & $66.4(0.99)$ \\
\hline 2. & Pothole Patching & $84.7(1.27)$ \\
\hline 3. & Patch Repair & $84.7(1.27)$ \\
\hline 4. & Rutting and Undulation Repair & $117.7(1.76)$ \\
\hline 5. & Tack Coat & $13.5(0.21)$ \\
\hline 6. & Liquid Seal Coat & $68.8(1.03)$ \\
\hline \multicolumn{3}{|c|}{ Periodic Maintenance } \\
\hline 1. & Single Bituminous Surface Dressing (SBSD) & $178.5(2.67)$ \\
\hline 2. & Double Bituminous Surface Dressing (DBSD) & $282.7(4.23)$ \\
\hline 3. & Premix Carpet (20mm PC) & $223.2(3.34)$ \\
\hline 4. & Mix Seal Surfacing (20 mm MSS) & $230.6(3.45)$ \\
\hline 5. & Semi Dense Bituminous Concrete (25mm SDBC) & 208.3(3.12) \\
\hline 6. & Bituminous Concrete (25mm BC) & $230.6(3.45)$ \\
\hline 7. & Bituminous Concrete (40mm BC) & $369.0(5.52)$ \\
\hline 8. & Bituminous Macadam (50mm BM) & $370.5(5.54)$ \\
\hline 9. & Dense Bituminous Macadam ( $75 \mathrm{~mm}$ DBM) & $614.5(9.19)$ \\
\hline 10. & Mill 90mm and Replace with (BM 50mm + BC 40mm) & 739.4(11.20) \\
\hline 11. & $\begin{array}{l}200 \mathrm{~mm} \text { Wet Mix Macadam + } 75 \mathrm{~mm} \text { Dense Bituminous Macadam + } \\
\text { 40mm Bituminous Concrete }\end{array}$ & $1429.8(21.38)$ \\
\hline
\end{tabular}

\subsection{Road User Cost (RUC) Data}

Road User Cost (RUC) consists of three components i.e., Vehicle Operating Costs (VOC), Travel Time Costs (TTC) and Accident Costs (AC). VOC is the dominating component in RUC. In present study, VOC component has been considered and has been calculated as per Clause 6.6 (Annexure C) and Clause 6.9 of IRC SP: 30, [13]. Table 11 shows vehicle operating cost data input per 1000 vehicles-km and economic cost (exclusive of tax) has been considered here.

\subsection{Proposed M\&R Alternatives}

Four M\&R alternatives have been proposed for this objective and given in Table 12 (keeping in mind the serviceability level of other roads).

\subsection{Comparative Study of Scheduled and Condition responsive M\&R Strategies}

Comparison of adopting a scheduled type $M \& R$ strategy against a condition responsive $M \& R$ strategy for individual road section throughout the analysis period has been done. Analysis period was taken as 12 years, start year with 2017 and PR-01 has been selected for Patiala city urban road network. Discount rate of $12 \%$ has been taken for present study. 
Table 11. Vehicle operating costs data input per 1,000 vehicle-km

\begin{tabular}{|c|c|c|c|c|c|c|c|}
\hline Parameter & $\begin{array}{c}\text { Two- } \\
\text { wheeler }\end{array}$ & Car/Jeep/Van & $\begin{array}{c}\text { Bus } \\
\text { (Medium) }\end{array}$ & Mini Bus & $\begin{array}{c}\text { Trucks } \\
\text { (Medium) }\end{array}$ & $\begin{array}{l}\text { Mini } \\
\text { Truck }\end{array}$ & $\begin{array}{c}\text { Tractor/Troll } \\
\text { ey }\end{array}$ \\
\hline Cost of & & & & & & & \\
\hline $\begin{array}{c}\text { Fuel } \\
(\operatorname{Rs}(\$) / \\
\text { litre) }\end{array}$ & $620(9.27)$ & $1400(20.93)$ & $5530(82.6)$ & $4570(68.4)$ & $5730(85.7)$ & $4570(68.32)$ & $4570(68.32)$ \\
\hline $\begin{array}{c}\text { Cost of } \\
\text { Lubricant } \\
\text { s(Rs(\$)/lit } \\
\text { re })\end{array}$ & $4(0.06)$ & $16(0.24)$ & $13(0.19)$ & $13(0.19)$ & $20(0.30)$ & $13(0.19)$ & $13(0.19)$ \\
\hline $\begin{array}{c}\text { Maintena } \\
\text { nce } \\
\text { Labour }\end{array}$ & $4.06(0.06)$ & $6.40(0.10)$ & $25.5(0.38)$ & $9.22(0.14)$ & $28.27(0.42)$ & $9.22(0.14)$ & $9.22(0.14)$ \\
\hline $\begin{array}{c}(\mathrm{Rs}(\mathrm{S}) / \mathrm{hr}) \\
\text { Crew } \\
\text { Wages } \\
(\mathrm{Rs}(\$) / \mathrm{hr})\end{array}$ & - & - & $1.17(0.02)$ & $4.08(0.06)$ & $2.20(0.03)$ & $4.08(0.06)$ & $4.08(0.06)$ \\
\hline $\begin{array}{c}\text { Annual } \\
\text { Overhead }\end{array}$ & $0.25(0.01)$ & $0.91(0.01)$ & $0.84(0.01)$ & $4.67(0.07)$ & $2.60(0.04)$ & $4.67(0.07)$ & $4.67(0.07)$ \\
\hline $\begin{array}{c}\text { Annual } \\
\text { Interest } \\
\text { ( in \%) }\end{array}$ & 8 & 8 & 8 & 8 & 8 & 8 & 8 \\
\hline
\end{tabular}

Table 12. Proposed M\&R alternatives

\begin{tabular}{|c|c|c|c|}
\hline M\&R Strategy & Works Standard & Description of Work & Intervention Level \\
\hline \multirow{2}{*}{$\begin{array}{l}\text { Base } \\
\text { Alternative }\end{array}$} & \multirow{2}{*}{ Routine } & Crack Sealing & Scheduled annually \\
\hline & & Patching & Scheduled annually \\
\hline \multirow[t]{2}{*}{ Alternative 1} & \multirow{2}{*}{$\begin{array}{l}\text { Resealing + } \\
\text { Thin Overlay }\end{array}$} & Provide $25 \mathrm{~mm}$ DBSD & $\begin{array}{l}\text { Total damage area }>8 \% \text { of total } \\
\text { area }\end{array}$ \\
\hline & & Provide $25 \mathrm{~mm} \mathrm{BC}$ & Roughness $>=4,<=5.8$ IRI \\
\hline Alternative 2 & Thick Overlay & Provide $40 \mathrm{~mm} \mathrm{BC}$ & Roughness $>=5.8,<=8$ IRI \\
\hline Alternative 3 & Reconstruction & $\begin{array}{l}\text { Provide }(200 \mathrm{~mm} \text { Wet Mix } \\
\text { Macadam }+75 \mathrm{~mm} \text { Dense } \\
\text { Bituminous Macadam }+40 \mathrm{~mm} \\
\text { Bituminous Concrete })\end{array}$ & Roughness $>=8$ IRI \\
\hline
\end{tabular}

\subsubsection{Proposed M\&R Alternatives}

The Scheduled $M \& R$ strategy has been chosen as per the current maintenance norms provided in MORT\&H, [19], where as the Condition Responsive M\&R strategy has been selected as per the serviceability levels up to which the respective pavement section is to be maintained (Guidelines for Maintenance of Primary, Secondary and Urban Roads, MORT\&H, [22]). Proposed M\&R Alternatives have been presented in Table 13.

\section{Results and Discussions}

\subsection{Determination of Optimum M\&R Strategy for All the Selected Road Sections}

Economic analysis for the selected roads has been done with discount of $12 \%$ (Clause 7.8 , IRC: SP: 30, [13]). As a result of this analysis, the road pavement deterioration/works reports and $M \& R$ works reports have been generated corresponding to each $M \& R$ alternative 
considered. The Roughness progression graphs of all the four alternatives for all the four road sections are shown individually from Figure 3 to Figure 6. The roughness progression has been traced to know whether the works have been correctly triggered according to the specified intervention criteria or not.

Table 13. Proposed M\&R alternatives for project analysis of PR-04

\begin{tabular}{|c|c|c|c|}
\hline M\&R Alternative & M\&R Work & Work Item & Intervention Criteria \\
\hline Routine Maintenance & Routine & $\begin{array}{l}\text { Patching } \\
\text { Crack Sealing }\end{array}$ & $\begin{array}{l}\text { Scheduled Annually } \\
\text { Scheduled Annually }\end{array}$ \\
\hline Scheduled Overlay & $\begin{array}{l}\text { Bituminous Concrete } \\
\text { (BC) } 25 \mathrm{~mm} \text { Thick }\end{array}$ & Provide BC $25 \mathrm{~mm}$ & $\begin{array}{l}\text { Scheduled every Five } \\
\text { years }\end{array}$ \\
\hline $\begin{array}{l}\text { Condition } \\
\text { Overlay }\end{array}$ & $\begin{array}{l}\text { Bituminous Concrete } \\
\text { (BC) } 25 \mathrm{~mm} \text { Thick }\end{array}$ & Provide BC $25 \mathrm{~mm}$ & $\begin{array}{l}\text { Roughness > }>4.0 \mathrm{~m} / \mathrm{km} \\
\text { IRI }\end{array}$ \\
\hline
\end{tabular}

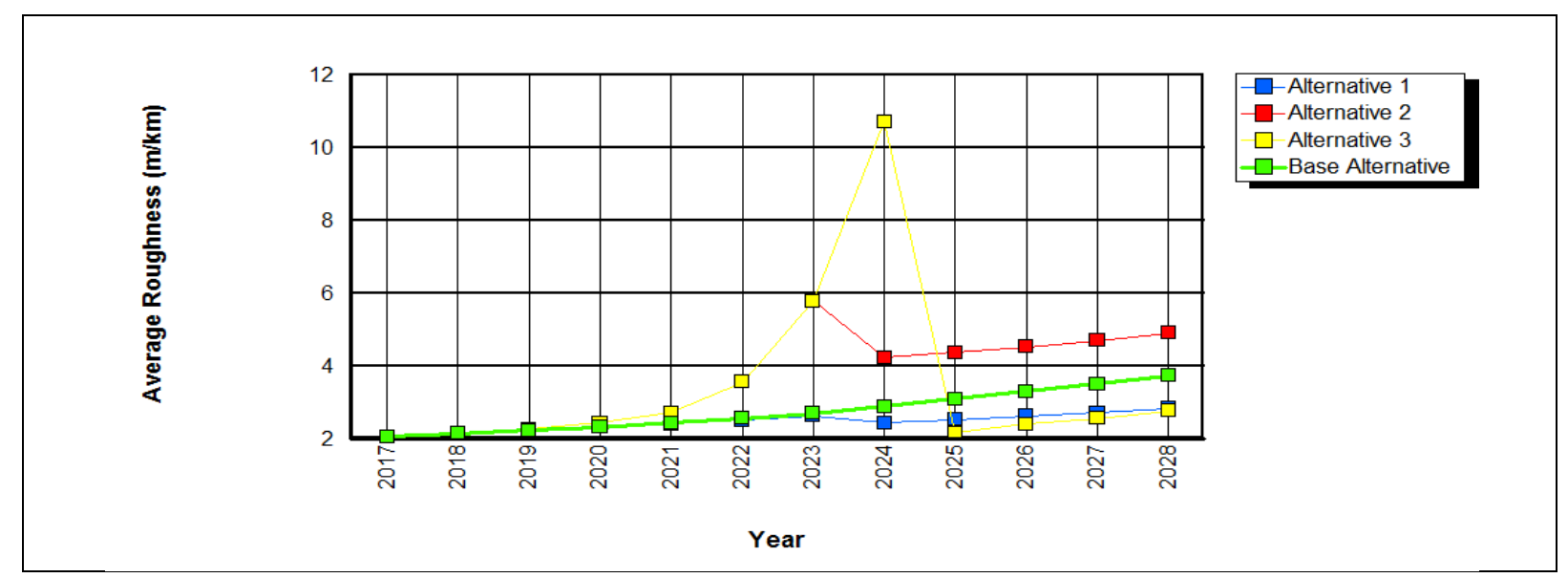

Fig. 3. Roughness progressions under all alternatives for PR-01

Roughness is considered to be the most useful indicator of the pavement deterioration, or average condition of the pavement section at any given point of time. The effect of the works to be carried out under each M \& R strategy, on average roughness of the selected pavement sections has been shown in Figure 3 to Figure 6. The progression of roughness can be tracked to check that the works have correctly triggered according to the specified intervention criteria; as for road section PR-04(shown in Figure 6), 'reconstruction' has been triggered under Alternative 3 at the end of the year 2022 (peak value in PR-04 with Alternative 3 graph line) for the road section PR-04, when the average roughness value for the pavement section has crossed the intervention level of $8 \mathrm{~m} / \mathrm{km}$ IRI. Similarly, Alterative 2 of 'overlay' has been triggered, when roughness value exceeds $5.8 \mathrm{~m} / \mathrm{km}$ IRI, in the year 2022 . This application of overlay has been indicated by drop in roughness value to $4.0 \mathrm{~m} / \mathrm{km}$. 


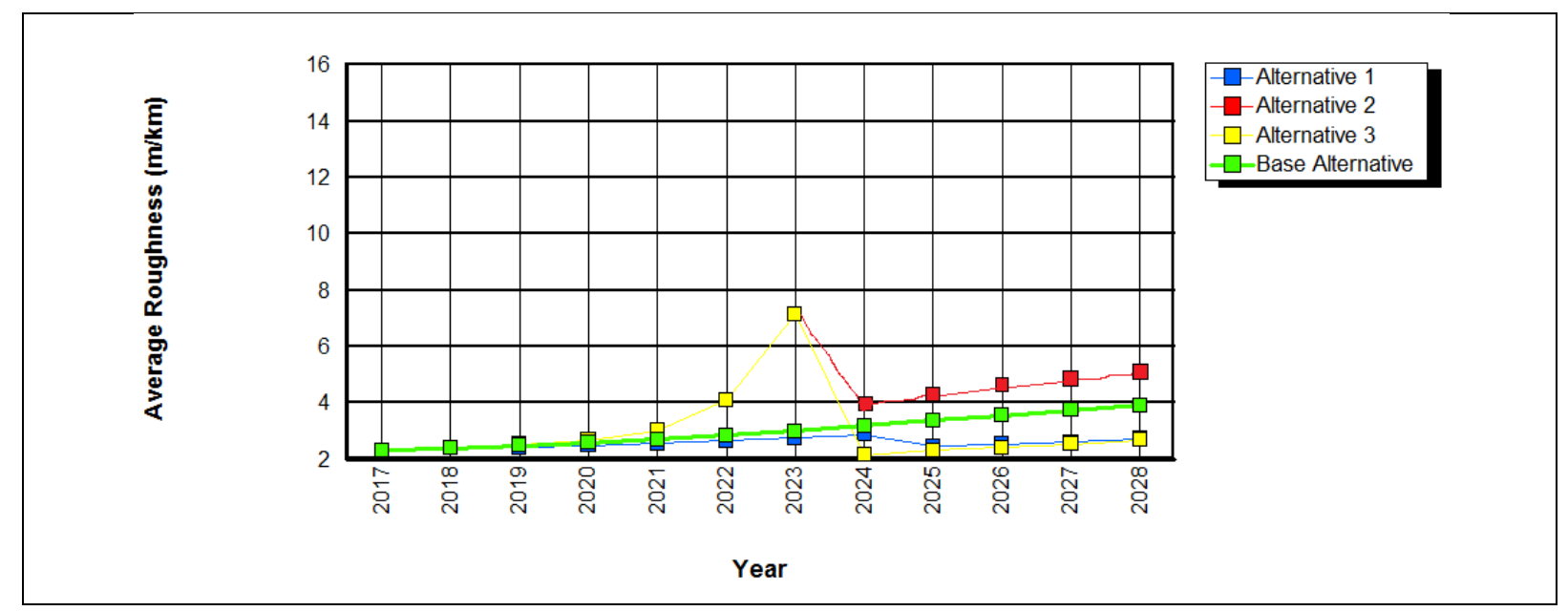

Fig. 4. Roughness progressions under all alternatives for PR-02
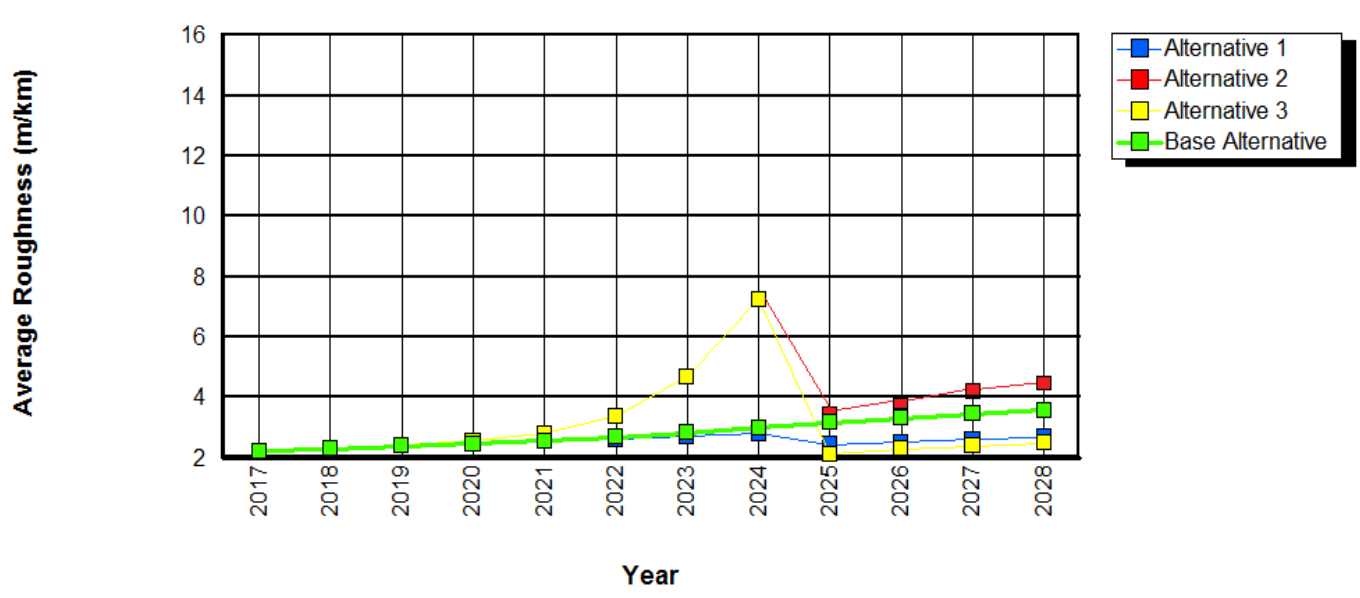

Fig. 5. Roughness progressions under all alternatives for PR-03
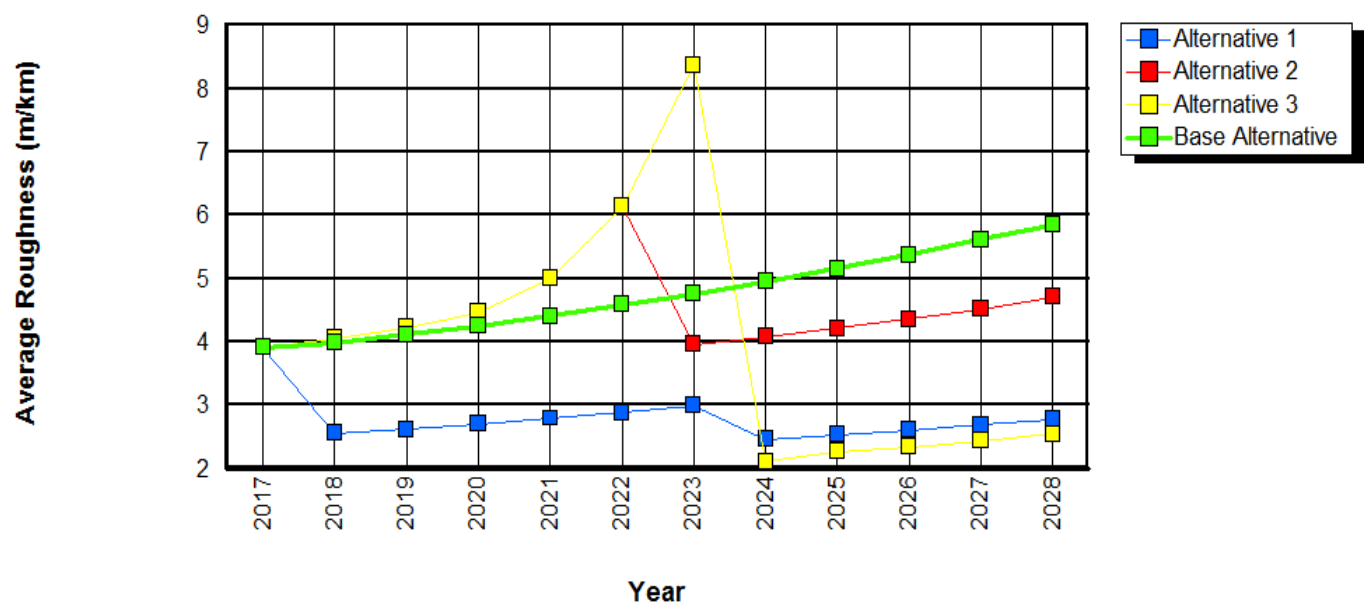

Fig. 6. Roughness progressions under all alternatives for PR-04

The year-wise summary report of each alternative for all the road sections have been mentioned in Table 14 to Table 16. This report has given the description of works that would be implemented in each year of the analysis period (2017-2028), under each M\&R strategy. Year-wise summary reports for all the four road sections corresponding to each alternative 
presented in Table 15 to Table 16. In Table 16, Alternative 1 i.e., 'Resealing + thin overlay' will be required in year 2018, 2023 and 2028 for PR-01; in year 2018 and 2024 for PR-02; in year 2017 for PR-03 and in year 2023 for PR-04 during the analysis period of 12 years (2017 - 2028). Alternative 2 i.e., ' $40 \mathrm{~mm} \mathrm{BC'}$ ' will be applied in year 2023 for section PR-01 and PR02, in year 2024 for PR-03 and in year 2022 for section PR-04 as shown in Table 15. Alternative 3 i.e., 'reconstruction' will be applied in year 2023 for PR-02 and PR-04 and in year 2024 for PR-01 and PR-03 as shown in Table 16. Selection of optimum M\&R strategy by economic analysis has based on any of the economic indicators i.e., Net Present Value/Cost (NPV/Cost) Ratio, Internal Rate of Return (IRR) or Net Benefits. In the present study, economic indicator NPV/Cost ratio has been considered for selection of optimum M\&R strategy for all the road sections. The summaries of economic analysis for all the road sections are shown in Table 17 to Table 20.

Table 14. Year-wise summary report of Alternative 1 for all road sections

\begin{tabular}{|c|c|c|c|c|}
\hline \multirow[b]{2}{*}{ Year } & \multicolumn{4}{|c|}{ Alternative 1} \\
\hline & PR-01 & PR-02 & PR-03 & PR-04 \\
\hline 2017 & $* * * *$ & $* * * *$ & $* * * *$ & $25 \mathrm{~mm}$ DBSD \\
\hline 2018 & $25 \mathrm{~mm}$ DBSD & $25 \mathrm{~mm}$ DBSD & $25 \mathrm{~mm}$ DBSD & $* * * *$ \\
\hline 2023 & $25 \mathrm{~mm}$ DBSD & $* * * *$ & $* * * *$ & $25 \mathrm{~mm}$ DBSD \\
\hline 2024 & $* * * *$ & $25 \mathrm{~mm}$ DBSD & $25 \mathrm{~mm}$ DBSD & $* * * *$ \\
\hline 2028 & $25 \mathrm{~mm}$ DBSD & $* * * *$ & $* * * *$ & $* * * *$ \\
\hline
\end{tabular}

**** means no M\&R work assigned in the certain year

Table 15. Year-wise summary report of Alternative 2 for all road sections

\begin{tabular}{ccccc}
\hline & \multicolumn{4}{c}{ Alternative 2 } \\
\cline { 2 - 5 } Year & PR-01 & PR-02 & PR-03 & PR-04 \\
\hline 2022 & $* * * *$ & $* * *$ & $* * * *$ & $40 \mathrm{~mm} \mathrm{BC}$ \\
2023 & $40 \mathrm{~mm} \mathrm{BC}$ & $40 \mathrm{~mm} \mathrm{BC}$ & $* * * *$ & $* * * *$ \\
2024 & $* * * *$ & $* * * *$ & $40 \mathrm{~mm} \mathrm{BC}$ & $* * * *$ \\
\hline
\end{tabular}

Table 16. Year-wise summary report of Alternative 3 for all road sections

\begin{tabular}{|c|c|c|c|c|}
\hline \multirow[b]{2}{*}{ Year } & \multicolumn{4}{|c|}{ Alternative 3} \\
\hline & PR-01 & PR-02 & PR-03 & PR-04 \\
\hline 2023 & $* * * *$ & $\begin{array}{c}200 \mathrm{~mm} \mathrm{WMM}+75 \\
\mathrm{~mm} \mathrm{DBM}+40 \mathrm{~mm} \\
\text { BC }\end{array}$ & $* * * *$ & $\begin{array}{c}200 \mathrm{~mm} \mathrm{WMM}+75 \\
\mathrm{~mm} \mathrm{DBM}+40 \mathrm{~mm} \\
\mathrm{BC}\end{array}$ \\
\hline 2024 & $\begin{array}{c}200 \mathrm{~mm} \mathrm{WMM}+75 \\
\mathrm{~mm} \mathrm{DBM}+40 \mathrm{~mm} \\
\mathrm{BC}\end{array}$ & $* * * *$ & $\begin{array}{c}200 \mathrm{~mm} \mathrm{WMM}+75 \\
\mathrm{~mm} \mathrm{DBM}+40 \mathrm{~mm} \\
\mathrm{BC}\end{array}$ & $* * * *$ \\
\hline
\end{tabular}

Table 17. Summary of economic analysis for PR-01

\begin{tabular}{|c|c|c|c|c|c|c|}
\hline Alternative & $\begin{array}{l}\text { Present value } \\
\text { of Road } \\
\text { Agency } \\
\text { Costs, Rs }(\$) \\
\text { in Millions }\end{array}$ & $\begin{array}{l}\text { Increase in } \\
\text { Agency } \\
\text { Cost, Rs }(\$) \\
\text { in Millions }\end{array}$ & $\begin{array}{c}\text { Decrease in } \\
\text { Road User } \\
\text { Costs, Rs }(\$) \text { in } \\
\text { Millions }\end{array}$ & $\begin{array}{l}\text { Net Present } \\
\text { Value, } \\
\text { Rs }(\$) \text { in } \\
\text { Millions }\end{array}$ & $\begin{array}{c}\text { NPV/Cost } \\
\text { Ratio }\end{array}$ & $\begin{array}{l}\text { Internal } \\
\text { Rate of } \\
\text { Return }\end{array}$ \\
\hline $\begin{array}{l}\text { Base } \\
\text { Alternative }\end{array}$ & $0.154(2264)$ & 0.000 & 0.000 & 0.000 & 0.000 & 0.000 \\
\hline Alternative 1 & $3.996(58764)$ & $3.842(56500)$ & 26.092(383705) & $22.250(327205)$ & 5.568 & 51.5 \\
\hline Alternative 2 & $1.570(23088)$ & $1.416(20823)$ & $2.918(42911)$ & $1.502(22088)$ & 0.957 & 21.03 \\
\hline Alternative 3 & $5.434(79911)$ & $5.279(77632)$ & $8.186(120382)$ & $2.907(42750)$ & 0.535 & 16.8 \\
\hline
\end{tabular}


Table 18. Summary of economic analysis for PR-02

\begin{tabular}{lcccccc}
\hline Alternative & $\begin{array}{c}\text { Present value } \\
\text { of Road } \\
\text { Agency Costs, } \\
\text { Rs(\$) in } \\
\text { Millions }\end{array}$ & $\begin{array}{c}\text { Increase in } \\
\text { Agency Cost, } \\
\text { Rs } \$ \text { (\$) in } \\
\text { Millions }\end{array}$ & $\begin{array}{c}\text { Decrease in } \\
\text { Road User } \\
\text { Costs, Rs } \$ \text { ) in } \\
\text { Millions }\end{array}$ & $\begin{array}{c}\text { Net Present } \\
\text { Value, Rs }(\$) \text { in } \\
\text { Millions }\end{array}$ & $\begin{array}{c}\text { NPV/Cost } \\
\text { Ratio }\end{array}$ & $\begin{array}{c}\text { Internal } \\
\text { Rate of } \\
\text { Return }\end{array}$ \\
\hline $\begin{array}{l}\text { Base Altern } \\
\text { ative }\end{array}$ & $\begin{array}{c}0.250(3676) \\
\text { Alternative 1 }\end{array}$ & 0.000 & 0.000 & 0.000 & 0.000 & 0.000 \\
Alternative 2 & $5.083(74750)$ & $4.834(71088)$ & $22.358(328794)$ & $17.525(257720)$ & 3.448 & 46.1 \\
Alternative 3 & $9.708(142764)$ & $9.458(139088)$ & $15.389(226308)$ & $5.931(87220)$ & 0.611 & 17.2 \\
\hline
\end{tabular}

Table 19. Summary of economic analysis for PR-03

\begin{tabular}{lcccccc}
\hline Alternative & $\begin{array}{c}\text { Present value } \\
\text { of Road } \\
\text { Agency } \\
\text { Costs, Rs(\$) } \\
\text { in Millions }\end{array}$ & $\begin{array}{c}\text { Increase in } \\
\text { Agency } \\
\text { Cost, Rs } \$ \text { in Millions }\end{array}$ & $\begin{array}{c}\text { Decrease in } \\
\text { Road User } \\
\text { Costs, Rs(\$) } \\
\text { in Millions }\end{array}$ & $\begin{array}{c}\text { Net Present } \\
\text { Value, Rs(\$) } \\
\text { in Millions }\end{array}$ & $\begin{array}{c}\text { NPV/Cost } \\
\text { Ratio }\end{array}$ & $\begin{array}{c}\text { Internal } \\
\text { Rate of } \\
\text { Return }\end{array}$ \\
\hline Base & $0.120(1764)$ & 0.000 & 0.000 & 0.000 & 0.000 & 0.000 \\
Alternative & & & & & & \\
Alternative 1 & $2.466(36264)$ & $2.346(34500)$ & $7.504(110352)$ & $5.158(75852)$ & 2.092 & 33.0 \\
Alternative 2 & $2.399(35279)$ & $2.279(33514)$ & $3.452(50764)$ & $1.173(17250)$ & 0.489 & 14.7 \\
Alternative 3 & $4.205(61838)$ & $4.085(60073)$ & $6.216(91411)$ & $2.131(31338)$ & 0.507 & 15.3 \\
\hline
\end{tabular}

Table 20. Summary of economic analysis for PR-04

\begin{tabular}{lcccccc}
\hline Alternative & $\begin{array}{c}\text { Present value } \\
\text { of Road } \\
\text { Agency, } \\
\text { Costs Rs(\$) } \\
\text { in Millions }\end{array}$ & $\begin{array}{c}\text { Increase in } \\
\text { Agency } \\
\text { Cost, Rs(\$) } \\
\text { in Millions }\end{array}$ & $\begin{array}{c}\text { Decrease in } \\
\text { Road User } \\
\text { Costs, Rs(\$) in } \\
\text { Millions }\end{array}$ & $\begin{array}{c}\text { Net Present } \\
\text { Value, Rs(\$) in } \\
\text { Millions }\end{array}$ & $\begin{array}{c}\text { NPV/Cost } \\
\text { Ratio }\end{array}$ & $\begin{array}{c}\text { Internal } \\
\text { Rate of } \\
\text { Return }\end{array}$ \\
\hline Base & $0.088(1294)$ & 0.000 & 0.000 & 0.000 & 0.000 & 0.000 \\
Alternative & & & & & & \\
Alternative 1 & $3.059(44985)$ & $2.972(43705)$ & $29.157(428779)$ & $26.186(385088)$ & 8.560 & 129.6 \\
Alternative 2 & $1.508(22176)$ & $1.420(20882)$ & $3.513(51661)$ & $2.093(30779)$ & 1.389 & 22.2 \\
Alternative 3 & $5.216(76705)$ & $5.129(75426)$ & $8.977(132014)$ & $3.848(56588)$ & 0.738 & 20.4 \\
\hline
\end{tabular}

On the basis of economic analysis of each alternative for all the road sections, optimum M\&R strategy has been selected. The alternative which has higher NPV/Cost ratio for any road section compared to the other predefined alternatives, is selected as optimum M\&R strategy for that section. Table 21 shows the optimum $M \& R$ alternative selected for each road section.

Table 21. Optimum M\&R Alternative for each road section

\begin{tabular}{ccc}
\hline Section ID & Section Name & Optimum M\&R Strategy \\
\hline PR-01 & Bhadson Road & Alternative 1 \\
PR-02 & Bhupinder Road & Alternative 1 \\
PR-03 & Passey Road & Alternative 1 \\
PR-04 & Ghuman Road & Alternative 1 \\
\hline
\end{tabular}

\subsection{Prioritization of Road Sections Based on Optimum M\&R Strategy}

Based on optimum M\&R strategy of the road sections, prioritization of all the road sections has been done. Higher the NPV/Cost ratio of optimum M\&R strategy of the road section, higher will be the prioritization ranking of that road. Table 22 shows the prioritization ranking of road sections based on optimum $M \& R$ strategy. 
Table 22. Prioritization ranking of road section

\begin{tabular}{clccc}
\hline Section ID & Section Name & Optimum M\&R Strategy & NPV/Cost Ratio & Prioritization Ranking \\
\hline PR-04 & Ghuman Road & Alternative 1 & 8.560 & 1 \\
PR-01 & Bhadson Road & Alternative 1 & 5.568 & 2 \\
PR-02 & Bhupinder Road & Alternative 1 & 3.448 & 3 \\
PR-03 & Passey Road & Alternative 1 & 2.092 & 4 \\
\hline
\end{tabular}

\subsection{Comparative Analysis of M\&R Strategies}

The Roughness progression graph of all the three alternatives for PR-01 has been shown in Figure 7. The roughness progression has been traced to know whether the works have been correctly triggered corresponding to the specified intervention criteria. In case of 'Condition Responsive Overlay' alternative, overlay work has been triggered as soon as the roughness value reaches 4 IRI. But in case of Scheduled overlay alternative, overlay work has been triggered in every five years, but roughness value of IRI is equal to $2.4 \mathrm{~m} / \mathrm{km}$ or even less, which is well below the limiting value of IRI is equal to $4 \mathrm{~m} / \mathrm{km}$ (serviceability level for other roads). The various work items resulting from the two $M \& R$ alternatives specified, as triggered by the respective intervention parameters and timings of their application are shown in Table 23. Total road costs for both $M \& R$ alternatives have been shown. The cost comparison of the two defined M\&R alternatives clearly shows that in case of adopting Scheduled type M\&R strategy, road agency will have to spend Rupees 5.811 millions on overlaying the road section three times throughout the period of 12 years. However, in case they adopt Condition Responsive type M\&R strategy, the agency may have to spend only Rupees 1.937 million on overlaying the road section one time through the same period. In adopting the Scheduled type M\&R strategy, the road agency will have to spend about 3 times more than the cost of Condition Responsive M\&R strategy. Hence, there will be huge net saving in cost in case of Condition Responsive type M\&R strategy as compared to scheduled type M\&R strategy. The Condition Responsive M\&R strategy can hence be affirmed as cost effective M\&R strategy.

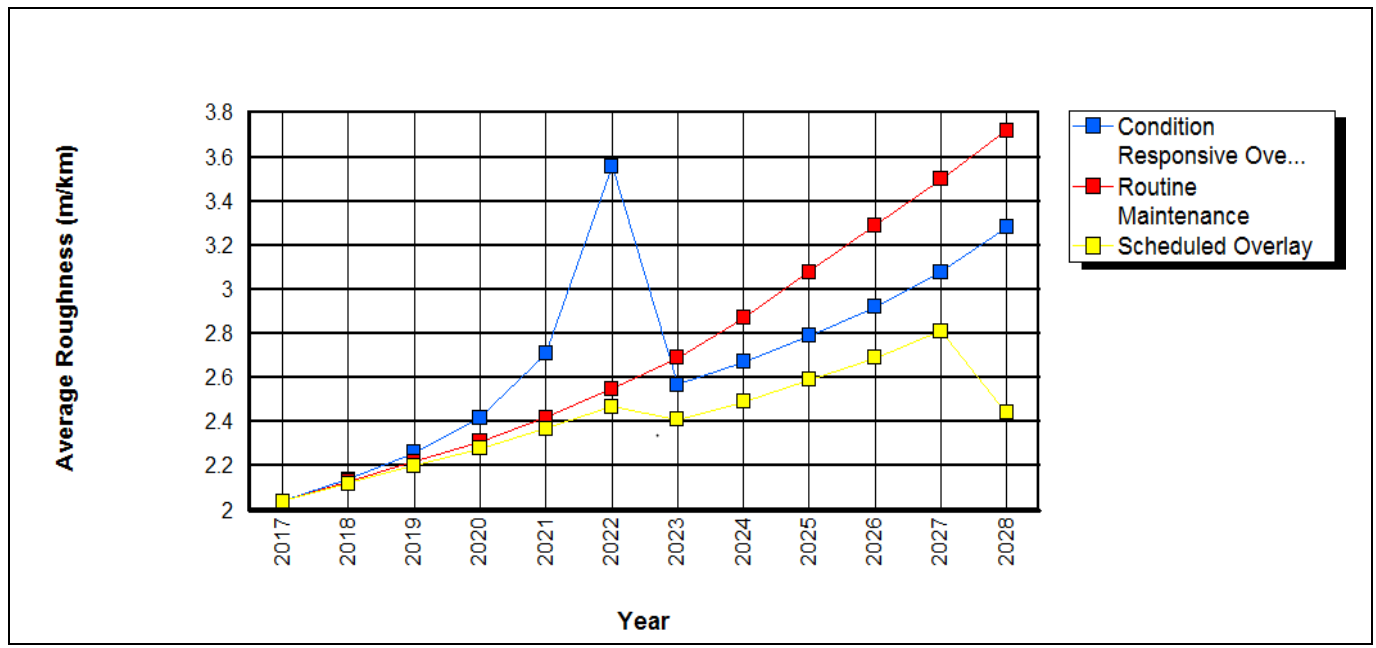

Fig. 7. Roughness progression under the three alternatives for PR-01 
Table 23. Description of M\&R works with total road agency costs

\begin{tabular}{|c|c|c|c|c|}
\hline $\begin{array}{c}\text { M\&R } \\
\text { Alternative }\end{array}$ & M\&R Work & $\begin{array}{l}\text { Applicable } \\
\text { Years }\end{array}$ & $\begin{array}{c}\text { Frequency of } \\
\text { Application }\end{array}$ & $\begin{array}{l}\text { Total Road Agency } \\
\text { Costs in Million } \\
\text { Rupees }\end{array}$ \\
\hline $\begin{array}{l}\text { Scheduled } \\
\text { Overlay }\end{array}$ & $\begin{array}{l}\text { Bituminous Concrete } 25 \\
\text { mm Thick }\end{array}$ & $\begin{array}{l}2017,2022, \\
2027\end{array}$ & 3 & 5.811 \\
\hline $\begin{array}{l}\text { Condition } \\
\text { Responsive } \\
\text { Overlay }\end{array}$ & $\begin{array}{l}\text { Bituminous Concrete } 25 \\
\text { mm Thick }\end{array}$ & 2022 & 1 & 1.937 \\
\hline
\end{tabular}

\section{Conclusions}

- The optimum M\&R strategy for all road section of Patiala city road network has been determined successfully based on highest NPV/cost ratio using HDM-4. Amongst a number of defined M\&R strategies; Alternative 1 i.e., 'Resealing + Thin Overlay' has been selected as optimum M\&R strategy for all the road sections. Hence, the use of PMMM techniques can lead to a coordinated, cost-effective strategy for maintaining pavements.

- On the basis of optimum M\&R strategy, prioritization of road sections for maintenance works has been successfully done for all the road sections. In case of constrained budget, maintenance of road sections could be done based on prioritization ranking of road sections i.e., first preference will be given to PR-04, second to PR-01, third to PR-02 and last preference will be PR-03 for maintenance work. The HDM-4 model effectively prioritizes all the road sections for the present study. Since, prioritization is a decision making process, designers must use good models like HDM-4 before taking important decisions.

- Comparative study of Scheduled type and Condition Responsive type M\&R strategies has been successfully carried out for Bhadson Road section. The cost comparison of the two defined $M \& R$ alternatives clearly show that in adopting the Scheduled type M\&R strategy, the road agency will have to spend about 3 times higher than the cost of Condition Responsive M\&R strategy. Condition Responsive $M \& R$ strategy is hence chosen as the cost effective M\&R strategy.

\section{References}

[1] Aggarwal, S., Jain, S.S and Parida, M., A critical appraisal of pavement management systems. Journal of Indian Road Congress, 63(2), 2002.

[2] Aggarwal, S., Jain, S.S and Parida, M., Development of pavement management system for Indian national highway network. Journal of Indian Road Congress, 65(2), 271-326, 2004.

[3] Aggarwal, S., Jain, S.S and Parida, M., Use of pavement management systems in Developing Countries, Indian Highways, 5 - 17, 2005.

[4] Archondo-Callao, R., Allying the HDM-4 model to strategic planning of road works, The World Bank Group, Washington, D.C., 2008.

[5] Aydin, M.M., Topal A., Effect of road surface deformations on lateral lane utilization and longitudinal driving behaviours, Transport, 31,192-201, 2016.

[6] Ben-Edigbe, J., Ferguson, N., Extent of capacity loss resulting from pavement distress, Proceedings of the Institution of Civil Engineers - Transport, 158(1): 27-32, 2005. 
[7] Ben-Edigbe, J., Assessment of speed-flow-density functions under adverse pavement condition, International Journal of Sustainable, Development and Planning, 5(3), 238-252, 2010.

[8] Dattatreya, J.K., Veeraragavan A., Murthy, K. and Justo, C.E.G., A suggested simplified system for pavement maintenance management of road network. Journal of Indian Roads Congress, 53(2), 217-273, 1992.

[9] Ghasemlou, K., Aydin, M.M., Yıldırım, M.S., Karpuz, O.and İmamoğlu, C.T., Investigation the effect of road surface deformations on capacity of signalized intersections by using cell transmission model, 11th International Congress on Advances in Civil Engineering, Istanbul, Türkiye, 1-10, 2014.

[10] Girimath, S. B. and Fellow, P., Pavement management system for urban roads. International Journal of Scientific and Development, 2(3), 282-284, 2014.

[11] Gupta, P. K., and Kumar, R., Development of optimum maintenance and rehabilitation strategies for urban bituminous concrete surfaced roads. International Journal of Scientific and Technology Research, 4(2), 56-66, 2015.

[12] IRC: 81, Guidelines for strengthening of flexible road pavement using benkelman beam deflection technique. Journal of Indian Roads Congress, New Delhi, 1997.

[13] IRC SP: 30, Manual on economic evaluation of highway projects in India. Journal of Indian Roads Congress, New Delhi, 2009.

[14] Jain, S. S., Aggarwal, S., and Parida, M., HDM-4 pavement deterioration models for Indian national highway network. Journal of Transportation Engineering, 131(8), 623-631, 2005.

[15] Jain, K., Jain, S. S., and Chauhan, M. S., Selection of Optimum Maintenance and Rehabilitation. International Journal for Traffic and Transportation Engineering, 3(3), 269-278, 2013.

[16] Kerali, H. R., Henry, G. R., Odoki, J. B. and Stannard, E. E., HDM-4, Overview of HDM-4. The World Road Association (PIARC), 2000.

[17] Government of Punjab, Master Plan Patiala, Department of town and country Planning Punjab, 2011.

[18] MORT\&H, Report of the committee on norms for maintenance of roads in India. Ministry of Road Transport \& Highways, Government of India, New Delhi, 2001a.

[19] MORT\&H, Road Development Plan Vision: 2021. Ministry of road transport \& highways, Government of India, New Delhi, $2001 \mathrm{~b}$.

[20] MORT\&H, Updation of road user cost data. Final Report prepared by Central Road Research Institute for Ministry of Road Transport \& Highways, Government of India, New Delhi, 2001c.

[21] MORT\&H, Specifications for maintenance works. Ministry of Road Transport \& Highways, Government of India, New Delhi, 2001d.

[22] MORT\&H, Specifications for maintenance works. Ministry of Road Transport \& Highways, Government of India, New Delhi, 2004.

[23] MORT\&H, Specifications for maintenance works. Ministry of Road Transport \& Highways, Government of India, New Delhi, 2013.

[24] Naidu, S.S., Nanda, P.K., Kalla, P., Sitaramanjaneyulu, K., Pavement maintenance management system for urban roads using software HDM-4 A Case Study. Journal of Indian Roads Congress, 66(3), 641- 669, 2005.

[25] Odoki, J. B. and Kerali, H. R., Analytical framework and model descriptions. The World Road Association (PIARC) on behalf of the ISOHDM sponsors, 2013.

[26] Pienaar, P. A., Visser, A. T. and Dlamini, L., A comparison of the HDM-4 with the HDM-III on a case study in Swaziland. South African Transport Conference. South Africa, 2000. 
[27] Reddy, B.B. and Veeraragavan, A., Priority ranking model for managing flexible pavement at management level, Centre for Transportation Engineering, Bangalore University, Bangalore, 378-394, 2001.

[28] Reddy, B.B. and Veeraragavan, A., Priority ranking model for managing flexible pavements at network level, Technical Paper Published in 62nd annual session of Indian Roads Congress( IRC), Kochi, India, 2002.

[29] Shah, Y. U., Jain, S. S. and Parida, M., Evaluation of prioritization methods for effective pavement maintenance of urban roads. International Journal of Pavement Engineering, 15(3), 238-250, 2012. 